\title{
CREDIT DEFAULT SWAP (CDS) SPREADS: THE ANALYSIS OF TIME SERIES FOR THE INTERACTION WITH THE INTEREST RATES AND THE GROWTH IN TURKISH ECONOMY
}

\author{
BILAL KARGI1
}

\begin{abstract}
This text is for the relation between credit default swap (CDS) spreads and some chosen macro economic data in Turkish economy. Credit default swap spread as an insurance spread is the most important sign for the solvency of the debitors in that country about the securities that public sector and companies export in an economy. Thus, the decisions of investors for the investment feasibility related to economy are based on the information that was supplied by these spreads. Therefore, the credit default swap spreads have become a kind of reliability index. Moreover, they have become an information source about the general view of economy except the investee securities. In this study, the relation between the interest rates of CDS spreads and GDP is determined over time.
\end{abstract}

KEY WORDS: Credit Default Swap Spreads, GDP, Interest Rates, Turkish Economy.

JEL classification: G24, 052, 040

Received: February 12, 2014 / Accepted: June 15, 2014

\section{INTRODUCTION}

When the economic theory contact with facts/real world, it reaches the macro theory by acting on the assumptions of the perfect competition market which becomes a theoretical market. The one of the most known features of the theoretical market model is that producers and consumers have "complete and full information" about the market. Another one is the supposed freedom of entry and exit to the market. If we look at the second one in detail from the both assumptions, we reach the induction of goods, employment, capital and other production factors and of economic values' free movement on a global scale. In this way, it will be precipitated that producers and consumers can easily reach all markets on a global scale and can generate supply and demand. To make possible induction that is obtained by the second assumption, it'll be possible that the first mentioned assumption can have "full" or minimum earnable high information about the markets. So, both assumptions coincide with each other. It is seen that producers and consumers, in other words, supply and demand can reach the economic values and economic information without any limitations on a global scale, and can walk around the world without limitation of their mobilities.

Here, all economic facts in the pratical world are statistically followed to be informed economy. However, when all acquired information for the markets are explained, it is perceived by the market agents, and the agents immediately organize their positions on the basis of the new data. Therefore, it is suggested that the economy is the imponderable dynamic mechanism (Fama, 1965). Because of the dynamic process, a "certain" forecast is not possible but "view" and "opinion" can be suggested. However, the market agents aren't always rational. Therefore, asset accounts are formed and behaviours include irrationality (Shiller,2005). So, it causes hesitation about view and opinion the extent to which consistent and reliable (Mora, 2005; Afonso andet al., 2011; ReisenandMaltzan, 1998; Flores, 2010). Even if, international investors continue to find the best information that might be possible about the economy prerequisite for an investment. In

\footnotetext{
${ }^{1}$ Aksaray University, Department of Banking and Finance, Aksaray, bilalkargi@gmail.com
} 
traditional, credit ratings that have been given to countries are in use since 1900's (Bessis, 2002:14). However, with especially Asian economic crisis (Gumrah, 2009.) and following 2000s, it hasn't reflected information global crisis 2008. Therefore, the orientation has accelerated to CDS (Credit Default Swap) spreads. CDS that was introduced by J. P. Morgan to be traded at financial markets fort he first time in 1995, has spread like wildfire.

Credit Default Swap is a policy that a reference agency export at risk of default for an asset transfers to the third party in reply to the periodical spread payment (Brandon and Fernandez, 2005). Credits that are opened to the companies in an economy or payment that will maket to the securities in that country, are directly proportional to the safety of investor that may take back this credit. The security locks with payable spread in certain periods with respest the risks in that economy to guarantee that the value of a security can repay (Andritzkyand Sing, 2006:3). These spreads are named as "Credit Default Swap Spread". These Spread notes that named as CDS with the most common usage, are policies that insure investment tool in reply to a certain spread, and are also investment tool itself. The most distinct feature it is its separation from the insurance policy. On the other hand, it escapes the "insurance" and "trade-in" expression used. Thus, a certain reserve should be at a spread, even if the "trade-in" expression is chosen to pass the required reserve necessity for the insurance policy (Markowitz, 2009). There are three topics for CDS policy (Desrosiers, 2007:21-22): protected creditor, debtor and policy firm. Thus, it promises the company that sell the policy in reply to a payable spread by the protected creditor, and in the event that default of the debtor, and promises that pay the credit with its capital and interst to the protected creditor (Chen, et al.,2011:5). Also, these CDS policies are processed at secondary markets. Accordingly, CDS policy to be invested means that the policy of debtor will default and at least he can't repay the credit. CDS spreads are defined with the open bidding procedure by International Swaps and Derivatives Association (ISDA) (Austin and Miller, 2011:2). The process of CDS in the secondary market is shortly "a cash flow transforms with other cash flow in the financial meaning. More generally, it is that the spread of security is exchanged with other security spread" (Delikanlı, 2010:90-91). It is often talked about the operand derivative "products in the secondary market, especially about Credit Default Swaps' (CDS) generalize and deeper effect for the global crisis. Recently, CDS' that grow fast and are the main investments that banks make and so that have mostly taken a major blow at the crisis period" (Akbay, 2011:7).

Especially in financial point, there is a wide literature for the relation with financial variables such as securities exchanges indices of CDS spreads, bonds and bills markets, and exchange rates. In this study, it is examined that the interest rates of the Turkish economy and the interaction between GSYIH and CDS spreads. Thus, the proofs have been tried to acquire that CDS spreads might be indicated the extent to which information content and economy about Turkey with reference to data of Turkish economy that becomes a developing market.

\section{THEORY AND LITERATURE}

It is mentioned that there are some studies that aren't enough for CDS, especially in Turkish literature. Especially, there are CDS studies for banking, finance and security market, it is also a minute amount. Therefore, an economotic study cannot be detected about its relation with the growth. CDS spreads include information about an investeee asset risk and fall of the economy when the spreads rise (IMF, 2013:59; Peristani and Savino 2011).

The studies for CDS try to determine whether or the safety indicator about markets, and concentrate its relation with the variables in financial markets. Empirical proofs are asked for the risk that may become effective to the investment decisions in markets. For example, Longstaff, et al., (2007) base on the data of 26 OECD countries, and CDS spreads have been examined subject to USA stock market, high-yield bond market, global risk appetite and capital flows, and credit ratings have been used as variables in this analysis". Also, Ismailescu and Kazemi (2010) have come through that "the credit rating increases leave a positive impression CDS spreads of countries in the short term. On the other hand, they emphasize that a limited increase in CDS spreads occured after the rating allowance because of that credit rating allowances generally 
have been reflected to CDS spreads of countries before now." (From, GurandOzturk, 2011:74).Elizalde (2005) shows that the relative magnitude of the future progresses haven't affected CDS spreads after the high performance of firms in the study that did through journal CDS spreads via six securities in Spain.

Sener, Ulutas and Cevik (2010a) who accented the necessity of "the relation that doesn't cause the arbitrage between Eurobond and CDS" in a well-functioning liquidity market, have precipitated that " the information of credit, bond and equity markets weren't reflected in prices at once, and the information flow principally started at equity markets". Moreover, "there are findings of the information flow toward which pass to the CDS through index, that the credit market was affected by the equity market" and "an investor, who will put under protection to Turkey through CDS, should closely follow the equity market, and any information flow shouldn't become to index through CDS." In a similar way, Akdogan and Chadwick (2012) who emphasize that CDS and EMBI + country values shouldn't cause the arbitrage; mention that the different periodical movements between two data were observed. By the data of the Turkish economy in their studies, have precipitated "the mentioned difference in a short term is quickly improved as proportional with the purchase and sale frequency ", and in a long term, didn't cause the arbitrage by acting in concert. Moreover, they have precipitated that CDS spreads mostly affected the liquidty effect instead of the bankrupt risk. In the study have been prepared by Keten, et al. (2013) "the relation has been detected between CDS and the interest rates for 30 years in a short term". Also, according to the results of Granger causality test, "it has been precipitated that there is "an unidirectional causality to five-year CDS spreads of Turkey." and has been indicated that this relation is also effective for the short and long term.

Ersan and Gunay (2009) have used the political developments as a dummy variable, and have precipitated that these political developments aren't statistically the meaningful effect for CDS spreads in their studies. Nevertheless, the authors who mention that the political and social developments' positive and negative effects are inevitable on the markets, have remarked that the information for the dummy variable have been previously priced by the market. Therefore, in the beginning they connect that "there is no effect" have been precipitated instead of "the negative effect on CDS", with this "early pricing" in their studies. Other acquired finding is that the maximum efficaciouses on CDS in Turkey are the Dow Jones index and the indicative eurobond interest forward 2030, and IMKB 100 index and the domestic indicative interest rates aren't effective on CDS on the basis of Granger causalities. Skinner and Townend (2002) remarked that the developing capacity of the derivative markets, and state that the operand amount of CDS product and the credit risk are open to manipulation.

Chen, et al., (2005) have prepiritated that even if there is a difference between the credit rating agencies, in any case, they are in relation between the interest rates in their studies which include the relation between CDS spreads for the interest rates and the branchs of the different industry. Also, they have prepiritated that even if the credit risk dynamics show the sectoral differences, they have interaction with the interest rates. Tang and Yan (2010) have prepiriated that there is an effect with CDS data rated $6 \%$ in their studies which include the growth rate and the investor sentiment variables. While the growth fluctuations are efficient on the liquidity flows, and the high cash flow in the growth terms of the economy, this relation become reversed in the period of recession. Liu and Morley (2012) have found that the effects of the exchange rates on CDS show the differences from country to country, and a dominant CDS- Rate relation isn't observed but even if the Exchange rates are a quite efficient on CDS. Accorrding to the acquired finding, it isn't talked about the relation of a general rate-CDS, and have mentioned that the rate is an active determinant. Therefore, the differences of the effects that direct the the exchange rate for every economy, also make a difference on CDS. Dieckmann and Plank (2012) state that CDS spreads rise in European economies after the financial crisis, and a contingent fluctuation in financial system is also reflected to the financial world system, and it rises the CDS spreads. This situation shows that there should be a system that transfers the risks to the financial system initiative saving for the public sector in the fluctutations. 
Fabozzi, Cheng and Chen (2007) theoretically submit that the risk rate, the effect of the industy sector, credit rating and liquidity factors are efficient for determining CDS spreads. They state that when the liquidity is high even if CDS spreads are low, when CDS spreads are low, there is no prof for the rise of the liquidity. In their model, they have used the interest rate, the credit rating of the country and the variables of the liquidity factors, and have precipitated that all variables are efficient on CDS. In these variables, especially they remark that CDS spreads are high when the liquidity is high, and in liquidity congestion for CDS spreads, the incremental costs come to the spreads.

Baum and Wan (2010) confirm the result of CDS spreads' rise under the economic uncertainty. They support the literature that eg. The interest rate risks and macroeconomic uncertainty are highly efficient on CDS. Especially the importance of CDS comes out after the financial crisis 2007-2008, and the collapse of Lehman Brothers is an example to it, Chiaramonte and Casu (2012). The credit default swap spread provides the low-priced and the effective promotion to the negative risks. Besides that, CDS spreads are an indication as to the level for the clarification of the developing derivatives markets, Yu and Zhong (2010).

This type of a study hasn't been detected for the growth data relating to Turkish economy. Therefore, this study is a primer but there are some studies and findings for Turkey and the financial markets. It is talked about the generalising and deepening effect of Credit Default Swaps (CDS) for the global crisis. Recently, CDS' that quickly develop and is the main that the banks mostly invest the instruments, are the instrument that take the first major blow" (Akbay, 2011:7). When the financial tension rises, both countries that have the debt crisis affect negatively each other and andnegatively affect developing countries with regards to the credit risk (CamgozandSevgi, 2012). It is stated that the political developments in Turkey aren't efficient on CDS, and Eurobond and Dow Jones index are efficient on CDS by Ersan and Gunay (2009).

\section{DATA AND METHOD}

The quarter datas are used belonging to 2005:01 - 2013: 03 period to understand the relation between CDS spread-GDP and the interest rate in the analysis. These datas have been acquired by the data base of CBRT-EDDS(Central Bank of Republic of Turkey-Electronic Data Delivery System) and Bloomberg. GDP quarter datas are in terms of seasonally adjusted US dollar. The quarter datas have been acquired by calculating the arithmetic mean for three months of CDS spreads (CDS) journal close data. The market interest rate (IRT) is the interest rate for the indicative papers of the Government Debt Securities. Political interest (LON) is Late Liquidity Window Facility Lendin Interest Rate of Central Bank.

Five different tests have been used in the study that the relation is tested between GDP, CDS and Interest Rates. (ADF Test) by Dickey and Fuller (1979), and (PP Test) by Phillips and Perron(1988) unit root test have been used for the stability test of series. (EG Test) by Engle and Granger (1987) have been used for researching the relation between two variables in a long term, and (JJ Test) by Johansen-Juselius(1990) have been used to Cointegration Tests for the long term test about more than two variables. Finally, (GC Test) by Granger (1969) Causality Test has been referred to be identified the asset and the side of the short term causality relation.

\section{EMPRICAL RESULTS}

The analysis is based upon four basic time series tests. It should be determined that the series whether or not include the unit root up to the next three tests. The series include the unit root, it means that it is not constant. Therefore, a fluctuating series should be changed to the constant by realising the difference process. ADF unit root test by Dcikey and Fuller and PP unit root test by Philips and Perron have been referred to understand the stability of the series. The acquired results have been shown in Table-1. 
Table 1: ADF and PP Unit Root Tests

\begin{tabular}{ccccc}
\hline & ADF & ADF $\Delta$ & \multicolumn{1}{c}{ PP } & PP $\Delta$ \\
\hline \multirow{2}{*}{ GDP } & $-2,445130$ & $-6,814116$ & $-2,383555$ & $-12,14580$ \\
& $(-2,951125)$ & $(-2,960411)$ & $(-2,951125)$ & $(-2,954021)$ \\
\cline { 2 - 5 } CDS & $-2,884649$ & $-7,157402$ & $-2,015465$ & $-7,157402$ \\
& $(-2,951125)$ & $(-2,954021)$ & $(-2,951125)$ & $(-2,954021)$ \\
\cline { 2 - 5 } IRT & $-1,548235$ & $-8,170365$ & $-1,372531$ & $-8,170365$ \\
& $(-2,951125)$ & $(-2,954021)$ & $(-2,951125)$ & $(-2,954021)$ \\
\cline { 2 - 5 } LON & $-0,918374$ & $-4,544846$ & $-0,944146$ & $-4,544846$ \\
& $(-2,615817)$ & $(-2,954021)$ & $(-2,951125)$ & $(-2,954021)$ \\
\hline
\end{tabular}

ADF test statistics (ADF Column) has been given in Table-1. The values in brackets are the critical values for $5 \%$ the meaning level. When $A D F<$ Critical Value, the series are concluded to the unit root context. Therefore, the acquired ADF test statistics (ADF $\Delta$ ) and the critical values have been given in brackets by taking the difference 1 of the series. As it is seen, all series can change to the constant when their differences were taken. The same procedure is also effective for PP test, and it is seen that PP test results are constant when all series differences 1 were taken.

A long term Co-Integration Test by Engle and Granger can be in progress because the series are equally constant. The acquired results are given in Table-2 for this test.

Table 2: Engle-Granger Co-Integration Test

\begin{tabular}{|c|c|c|c|c|}
\hline (a) Regressions & coefficient & Std. Deviation & \multicolumn{2}{|c|}{ t-Stat. } \\
\hline$d G D P=f(d C D S)$ & $-29505,11$ & 46611,03 & \multicolumn{2}{|c|}{$-0,633007$} \\
\hline$d G D P=f(d I N T)$ & -1534508 & 1546720 & \multicolumn{2}{|c|}{$-0,992104$} \\
\hline$d G D P=f(d L O N)$ & 3062193 & 2429262 & \multicolumn{2}{|c|}{1,260545} \\
\hline$d C D S=f(d G D P)$ & $-4,19$ & 6,62 & \multicolumn{2}{|c|}{$-0,633007$} \\
\hline$d C D S=f(d I N T)$ & 4,677923 & 5,860617 & \multicolumn{2}{|c|}{0,798196} \\
\hline$d C D S=f(d L O N)$ & 12,27317 & 9,126277 & \multicolumn{2}{|c|}{1,344817} \\
\hline \multicolumn{2}{|c|}{ Results of unit root test for error correction } & ADF & PP & Integre \\
\hline \multirow[t]{2}{*}{$d G D P=f(d C D S) \rightarrow u$} & & $\begin{array}{r}-6,519885 \\
(-2,960411)\end{array}$ & $\begin{array}{r}-12,27899 \\
(-2,954021)\end{array}$ & $\mathrm{I}(0)$ \\
\hline & & $\begin{array}{r}-6,089225 \\
(-2,960411)\end{array}$ & $\begin{array}{r}-9,924438 \\
(-2,954021)\end{array}$ & $\mathrm{I}(0)$ \\
\hline \multirow[t]{2}{*}{$\mathrm{dGDP}=\mathrm{f}(\mathrm{dLON}) \rightarrow \mathrm{u}$} & & $\begin{array}{r}-6,512291 \\
(-2,960411)\end{array}$ & $\begin{array}{r}-12,20899 \\
(-2,954021)\end{array}$ & $\mathrm{I}(0)$ \\
\hline & & $\begin{array}{r}-7,291860 \\
(-2,954021)\end{array}$ & $\begin{array}{r}-7,291860 \\
(2,954021)\end{array}$ & $\mathrm{I}(0)$ \\
\hline \multirow{2}{*}{$\mathrm{dCDS}=\mathrm{f}(\mathrm{dINT}) \rightarrow \mathrm{u}$} & & $\begin{array}{r}-7,551826 \\
(-2,954021)\end{array}$ & $\begin{array}{r}-7,653610 \\
(-2,954021)\end{array}$ & $\mathrm{I}(0)$ \\
\hline & & $\begin{array}{r}-7,472475 \\
(-2,954021\end{array}$ & $\begin{array}{r}-7,521611 \\
(-2,954021)\end{array}$ & $\mathrm{I}(0)$ \\
\hline
\end{tabular}

Engle-Granger Co-integration test that shows the long term relation between two variables, has just been calculated with the first differences which the variables become the constant. Principally, the coefficient, the standard errror and t-statistic values belonging to the creating VAR models, have been given in the panel (a) of Table-2. For the rule of this test assumption, the creating VAR models should be the constant by the level values of the error term. ADF and PP 
test results that are calculated for the error terms of each VAR models, are involved in the panel (b) of Table-2. As it seen, the error terms for each VAR models are the constant by their level values. In the present case, there is a long term relation from GDP to other variables and from CDS to other variables.

The current third test for analysis has been used as Johansen-Juselius co-integration test that was used for researching the co-integration relation between more than one variable, and the acquired results have been given in Table-3.

Table 3: Johansen-Juselius Co-Integration Test

\begin{tabular}{ccccccc}
\hline HO & H1 & Eigenvalue & Trace Stat. & 0,05 & Max-Eigen Stat. & 0,05 \\
\hline$r=0$ & $r \geq 1$ & 0,622509 & 66,77386 & 47,85613 & 31,17469 & 27,58434 \\
$r=1$ & $r \geq 2$ & 0,524689 & 35,59917 & 29,79707 & 23,80113 & 21,13162 \\
$r=2$ & $r \geq 3$ & 0,306790 & 11,79804 & 15,49471 & 11,72552 & 14,26460 \\
\hline
\end{tabular}

For JJ test results, "Trace Stat $>0,05$ the significance level" is supposed to be, and "MaxEigen Stat. > 0,05 the significance level" is supposed to be. HO hypothesis get rejected as long as these expectations occured, and $\mathrm{H} 1$ hypothesis is accepted and it is concluded that it's the cointegrated vector. Accordingly, it is said that there are the most two cointegrated vectors as result of JJ test.

There is a long term relation between the variables, so Granger Causality test has been used for researching the causality in a short term. The acquired results have been given in Table4.

Table 4: Granger Causality Test

\begin{tabular}{ccccc}
\hline & Chi-sq & df & Prob. & Result \\
\hline IRT $\rightarrow$ GDP & 8.677714 & 2 & 0,0131 & Granger Causality Exist \\
GDP $\rightarrow$ CDS & 23,67913 & 2 & 0,0000 & Granger Causality Exist \\
IRT $\rightarrow$ CDS & 10,83011 & 2 & 0,0044 & Granger Causality Exist \\
GDP $\rightarrow$ IRT & 7,580410 & 2 & 0,0226 & Granger Causality Exist \\
CDS $\rightarrow$ IRT & 8,015159 & 2 & 0,0182 & Granger Causality Exist \\
CDS $\rightarrow$ LON & 6,769692 & 2 & 0,0339 & Granger Causality Exist \\
\hline
\end{tabular}

According to the results in Table-4, there are the causality relations from IRT variable to GDP and CDS variables; from GDP variable to CDS and IRT variables; from IRT variable to CDS variable; from CDS variable to IRT and LON variables. In the same time, there is a bi-directional causality between IRT and GDP; IRT and CDS variables.

Yet, there isn't a causality relation from CDS variable to GDP variable. Other unidirectional relation is from CDS variable to LON variable.

\section{CONCLUSIONS}

The aim of this study is to analyze the relation between GSYIH of the Turkish economy, the interest rate and CDS (Credit Default Swap) spreads that have been carefully started to follow in the recent period to internationally predict the credibility of the countries and macroeconomic outlook. The lot of commited empirical research show that the most efficient variable is the interest rates for CDS spreads. So, this result has ensued in this research. It has been precipitated that there is a long term relation between GDP, CDS, IRT and LON variables in the Turkish economy. In the same time, it has been detected that there is a bidirectional causality relation between CDS 
and the market interest rate (IRT). Also, it has been detected the same bidirectional relation for the market interest rates (IRT) and GDP. The original result of the research is that even if CDS datas have relation with GDP in a long term, it didn't have that relation in a short term. On the other hand, the political interest of Central Bank doesn't constitute the reason for CDS.

According to these results, CDS spreads are mostly affected by the market interest rates for Turkish economy, and each variable are the mutual reason for each other. In theory, when it is thought that this relation is in the same way; when the market interests rise, CDS spreads also rise. The raise in CDS spreads (with the rise in the interest rates) are seen as a variable that cause the fall of the GDP. So, CDS spreads are the followed indication as an indicator for the growth datas of the Turkish economy.

\section{REFERENCES}

Akbay, O. S. (2011), "KüreselFinansalKrizinKökenleriÜzerineBirDeğerlendirme", Namık Kemal Üniversitesi,SosyalBilimlerMetinleri, No. 6, 1-16.

Akdoğan, K. and Chadwick, M. G. (2012),“CDS-Bono FarkıveDüzeltmeHareketi”, TCMB, EkonomiNotları, No.12/1, 1-9.

Afonso, A., Furceri, D. and Gomes, P. (2011), "Sovereign Credit Ratings and Financial Markets Linkages Application to European Data",Working Paper Series, European Central Bank, No. 1347.

Andritzky, J. and Singh, M. (2006), "The Pricing of Credit Default Swaps During Distress", Working Paper, IMF, No. 254.

Austin, D. A. and Miller R. S. (2011), "Treasury Securities and The U.S. Sovereign Credit Default Swap Market”, Congressional Research Service, CRS Report for Congress, No. 7-5700.

Baum, C. F. and Wan, C. (2010), "Macroeconomic Uncertainty and Credit Default Swap Spreads",Applied Financial Economics, No. 20, 1163-1171.

Bessis, J. (2002), Risk Management in Banking, Second Edition, John Wiley\&Sons Ltd., West Sussex.

Brandon, K. I. and Fernandez, F. A. (2005), "Financial Innovation and Risk Management: An Introduction to Credit Derivatives", Journal of Applied Finance, Vol. 15, No. 1, 52-63.

Cao, C., Yu, F.,Zhong, Z. (2010), "The Information Content of Option-Implied Volatility for Credit Default Swap Valuation", Journal of Financial Markets, No. 13, 321-343.

Chen, R., Cheng, W. and Wu, L. (2005), "Dynamic Interactions BetweenInterest Rate, Credit, and Liquidity Risks: Theory and Evidence from The Term Structure of Credit Default Swap Spreads", Social Science Research Network (http://dx.doi.org/10.2139/ssrn.779445).

Chen, K., Fleming, M., Jackson, J., Li, A. and Sakar, A. (2011), "An Analysis of CDS Transactions: Implications for Public Reporting",Staff Reports, Federal Reserve Bank of New York, No. 517.

Chiaramonte, L. and Casu, B. (2012), "The Determinants of Bank CDS Spreads: Evidence from the Financial Crisis",The European Journal of Finance, Vol. 19, No. 9, 861-887.

Delikanlı, I. U. (2010), "Bankacılıkta Kredi Türevlerinin Hissedar Değerine Katkısı, Etkin Bir Şekilde Kullanıma İmkan Sağlayacak Risk Yönetimi Yapılanmasıve Finansal Raporlaması”, Türkiye Bankalar Birliği, No. 271.

Desrosiers, M. E. (2007), "Prices of Credit Default Swap and The Term Structure of Credit Risk", A Professional Master's Project, Worcester Polytechnic Institute, USA.

Dickey, D. A. and Fuller, W. A. (1979), "Distribution of the Estimators of Autoregressive Time Series With a Unit Root", Journal of the American Statistical Association, Vol. 74, 427-431.

Dieckmann, S. and Plank, T. (2012), "Default Risk of Advanced Economies: An Empirical Analysis of Credit Default Swaps During the Financial Crisis", Review of Finance, No. 16, 903-934.

Eichengreen, B., Mody, A. Nedeljkovic, M. and Sarno, L. (2012), "How the Subprime Crisis Went Global: Evidence from Bank Credit Default Swap Spreads",Journal of International Money and Finance, No. 31, 1299-1318.

Elizalde, A. (2005), "Credit Default Swap Valuation: An Application to Spanish Firms", Centro de EstudiosMonetarios y Financieros (CEMFI), Master's Theses Series, No. 0303. (http://www.abelelizalde. com).

Engle, R. F. and Granger, C. W. J. (1987), "Co-integration and ErrosCorrection: Representation, Estimation, and Testing", Econometrica, Vol. 55, No. 2, 251-276.

Ersan, i. and Günay, S. (2009), "Kredi Risk Göstergesi Olarak Kredi Temerrüt Swapları (CDSs) ve Kapatma Davasının Türkiye Riski Üzerine Etkilerine Dair Bir Uygulama”, Bankacılar Dergisi, No. 71, 3-22. 
Fabozzi, F. J., Cheng, X. and Chen, R-R. (2007), "Exploring the Companents of Credit Risk in Credit Default Swaps",Finance Rend arch Letters, No. 4, 10-18.

Fama, E. F. (1965), "The Behavior of Stock-Market Price", The Journal of Business, Vol. 38, No. 1, 34-105.

Flores, E. (2010), “Do Sovereign Credit Rating Changes Have Spillover Effects on Other Countries?", Stanford University, Economics Department Theses.

Granger, C. W. J. (1969), "Investigating Causal Relations by Econometric Models and CrossSpectral Methods", Econometrica, Vol. 37, No. 3, 424-438.

Gür, T. H.,Öztürk, H. (2011), “ÜlkeRiski, Derecelendirme Kuruluşları, Aksaklıklarve Yeni Düzenlemeler, Sosyoekonomi, No. 2, 69-92.

Hacıhasanoğlu, R. and Soytaş, U. (2009), "S \& P500 Volatilitesive Türkiye'nin Kredilflas Takası Primi”, Celal Bayar Üniversitesi, Sosyal Bilimler Dergisi, Vol. 7, No. 2, 1-10.

IMF (2013), Global Financial Stability Report, (www.imf.org 06.01.2014).

Ismailescu, I. and Kazemi, H. (2010), "The Reaction of Emerging Market Credit Default Swap Spreads to Sovereign Credit Rating Changes", Journal of Banking and Finance, Vol. 34, No. 12, 2861-2873.

Johansen, S. and Juselius, K. (1990), "Maximum Likelihood and Inference on Cointegration - With Applications to the Demand for Money", Oxford Bulletin of Economics and Statistics, Vol. 52, No. 2, 169210.

Keten, M., Başarır, Ç. and Kılıç, Y. (2013), "Kredi Temerrüt Takası ile Makroekonomik ve Finansal Değişkenler Arasındaki iliş̧kinin İncelenmesi”, 17. Finans Sempozyumu Bildiriler Kitabı, Muğla, 377-386.

Liu, Y., Morley, B. (2011), “SoveringCredit Default Swaps and The Makroeconomy”, Applied Economics Letters, No. 19, 129-132.

Longstaff, A. F., Pan, J., Pedersen, L. H. and Singleton, K. J. (2007), "How Sovereign is Sovereign Credit Risk?", Working Paper, NBER, No. 13658.

Markowitz, H. M. (2009), "Proposals Concerning The Current Financial Crisis", Financial Analysts Journal, Vol. 65, No. 1, 25-27.

Mora, N. (2005), "Sovereign Credit Ratings: Guilty Beyond Reasonable Doubt?", Lecture and Working Paper Series, American University of Beirut Institute of Financial Economics, No. 1.

Peristiani, S. and Savino, V. (2011), "Are Credit DdefaultSwaps Associated With Higher Corporate Defaults?", Staff Reports, Federal Reserve Bank of New York, No. 494.

Phillips, P. C. B. and Perron, P. (1988), "Testing for an Unit Root in Time Series Regression", Biometrika, Vol. 75, 335-346.

Reisen, H. and Maltzan, J. (1998), "Sovereign Credit Ratings, Emerging Market Risk and Financial Market Volatility", Intereconomics, Vol. 33, No. 3, 73-82.

Shiller, R. J. (2005), "Behavioral Economics and Institutional Innovation", Discussion Paper,Cowles Foundation, No. 1499.

Skinner, F. S. and Townend, T. G. (2002), "An Empirical Analysis of Credit Default Swaps",International Review of Financial Analysis, No. 11, 297-307.

Şener, E., Ülütaş, S. and Çevik, P. (2010a), "Volatilite Yayılması-l: Vadeli Endeks Kontratları, Eurobond ve Kredi Temerrüt Takası", Vobjektif, No. 14, 55-57.

Şener, E., Ülütaş, S. and Çevik, P. (2010b), "Volatilite Yayılması-II: Endeks, Eurobond ve Kredi Temerrüt Takası", Vobjektif, Vol. 16, 53-56.

Tang, D. Y. and Yan, H. (2010),“Market Conditions, Default Risk and Credit Spreads”, Journal of Banking \& Finance, No. 34, 743-753. 